\title{
The Federation of Indian Organizations of the Negro River's journey for traditional land demarcation in Brazil
}

\author{
La jornada de la Federación de \\ Organizaciones Indígenas del Río Negro \\ para la demarcación de las tierras \\ tradicionales en Brasil
}

\author{
Fernanda Martinez de Oliveira*, Jacqueline Brigagão**, Peter Spink* \\ * Getulio Vargas Foundation; ** University of São Paulo
}

martinezoliveira@gmail.com

\begin{abstract}
The article aims to present the fight for government recognition of indigenous collective rights to land ownership in the Upper Rio Negro region in Brazil. It contextualizes the historical aspects of the colonization process in the region and the efforts to create the Federation of Indian Organizations of the Negro River (FOIRN). Focus of particular interest is how the organizational strategy adopted by the FOIRN has allowed the Indian population of the Upper Rio Negro to active participate in the land demarcation process, with their opinions heard and respected. The article was written with basis on information obtained from a variety of sources, such as documents, conversations and interviews with the main social actors involved in the area, carried out during a field visit to São Gabriel da Cachoeira in January 2010.
\end{abstract}

Palabras clave: Indigenous Demarcation; Organization; Brazil

\section{Resumen}

El artículo tiene como objetivo presentar la lucha por el reconocimiento gubernamental de los derechos colectivos indígenas de la propiedad de la tierra en la región del Alto Río Negro en Brasil. Se contextualizan los aspectos históricos del proceso de colonización de la región y los esfuerzos para crear la Federación de Organizaciones Indígenas del Río Negro (FOIRN). El foco de interés particular es cómo la estrategia de organización adoptada por la FOIRN ha permitido a la población indígena del Alto Río Negro participar activamente en el proceso de demarcación de tierras, escuchando y respetando sus opiniones. El artículo fue escrito con base en informaciones obtenidas de diversas fuentes, tales como documentos, conversaciones $y$ entrevistas con los principales actores sociales involucrados en el área, llevadas a cabo durante una visita a São Gabriel da Cachoeira, en enero de 2010.

Peoples; Land Keywords: Pueblos Indígenas; Demarcación de Tierras, Organización, Brasil

\section{Introduction}

In Brazil the process of recognition of Indian rights and citizenship has been slow and gradual. The 1988 Constitution represents a big advance in this process since it innovated in recognizing indigenous rights, abandoning the assimilations perspective present in the previous constitutions. It guarantees the recognition of indigenous collective rights and the notion of indigenous territorial rights as unalienable, that is, a right that existed before the State's creation itself and which cannot be abrogated by the state. In addition to all the rights ensured to Brazilian citizens, native populations had their rights to traditional 
lands, social organization, customs and languages recognized, including the right to public bilingual education. The constitution also stipulates that indigenous individuals, communities and organizations have the right to self-representation in defense of their rights and interests, an important landmark because, among others, it gives the opportunity to Original Peoples to constitute legal entities, capable not only to fundraise and manage their own resources, but to assume their own defense and interests.

The indigenous movement in Brazil, which began to organize in the 1970's, is currently very active in fighting for the recognition of the rights guaranteed in the Constitution of 1988 and also in trying to build new relationships with society and the Brazilian State, at all federative levels. This movement, which is very diverse and is mainly characterized by the formation of local organizations and associations, has developed activities in different regions of Brazil. In this text we will discuss how the native peoples who live in the Rio Negro region of the Amazon have organized themselves in the attempt to exercise their rights, forming the Federation of Indian Organizations of the Negro River (Federação das Organizações Indígenas do Rio Negro - FOIRN), which has carried out a number of actions seeking to guarantee indigenous autonomy and to pressure the State to create public policies which attend the demands of the native peoples. For this purpose, we will introduce the region's geopolitical characteristics, the historical context to the creation of FOIRN and the manner in which it is organized. Among the actions carried out to guarantee the Indians' rights to self govern, we will focus on work carried out by FOIRN within the Upper Rio Negro region to guarantee traditional land ownership.

This article was written with basis on information obtained from a variety of sources: documents, conversations and interviews with the main social actors involved in the area, carried out during a field visit to São Gabriel da Cachoeira in January 2010.

\section{The Rio Negro Region}

The Rio Negro hydrographic basin, located in the northwest of the Amazon, has been inhabited for at least two thousand years by ethnicities belonging to three different linguistic families, Tukano Oriental, Aruak and Maku. This region has borders with Brazil, Colombia and Venezuela and its boundaries form a picture which looks a little like a dog's head - the name by which the region is known.

Currently, São Gabriel has an estimated population of 39,129 inhabitants (IBGE 2007) and the native population makes up around $95 \%$ of the total local population. This is Brazil's second largest municipality in terms of area, with 112 thousand $\mathrm{Km}^{2}$. Over half of the municipal population lives in communities on the banks of the many rivers which make up the local geography. These rivers have many waterfalls and rapids which make water travel and the access to different communities difficult.

The area also has a population from the Northeast, Para and other parts of the country and the Amazon region, especially in the regional urban centers. In addition, the Upper Rio Negro has a constant military presence due to this being a border region, considered to be of geopolitical importance.

Despite the many differences and languages, the 23 ethnicities who live within the region make up one cultural area, in other words, there is a lot of interaction between the tribes, a network of exchange and identity in terms of culture and social organization, even though the construction of identity between the tribes is also often due to opposition among themselves. Besides the differentiation through linguistic family, it's possible to identify a certain geographic concentration of some ethnicities along some of the 
Rio Negro tributaries, such as the Rio Uaupés, the Rio Içana and the Rio Xié. Thus, along the Uaupés River we find mainly the Arapas, Bará, Barasana, Desana Karapanã, Kubeo, Makuna, Mirity-tapuya, Piratapuya, Siriano, Tariana, Tukano, Tuyuca, Kotiria, Tatuyo, Taiwano and Yuruti peoples. Along the Içana are the Baniwa and the Kuripako and on the Rio Xié, the Bare and the Werekena. It is worth noting that the native peoples of the Maku group, which includes the Hup'däh, Yohup, Nadëb and Dâw, are nomadic and may be found throughout the entire region.

Colonization in the Upper do Rio Negro region began in the mid $17^{\text {th }}$ century due to a decrease in the population in the lower Amazon, leading colonial settlers and missionaries from São Luís and Belém to travel through the Rio Negro and Amazon backcountry, capturing Indians and killing those who resisted. The slave trade was so intense during the 1740's that between then and the mid $18^{\text {th }}$ century an estimated 20 thousand Indians were captured and removed from the Upper Rio Negro. The lists of slaves removed from this region include large numbers of members of the Tukano, Baniwa Baré, Maku and Werekena ethnicities, among others. The majority were taken to work in Belém and São Luís.

The region was also marked by the presence of religious missionaries from different faiths. From the very beginning, the Salesian Catholic Missions attempted to eliminate the cultural manifestations of the Indians, showing a deep disregard for the native forms of organization and thought. In some tribes they were successful in convincing the Indians to abandon their communal homes and set up villages made up of individual family homes, using the argument of lack of hygiene and sexual promiscuity. They also campaigned against the activities of local witch doctors and forbade the consumption of traditional hallucinatory beverages, removing from homes decorative devices and ceremonial musical instruments. Since the Salesians were, for a long time, the only ones who provided minimal assistential infra-structure to the Indians, the Salesian Missions broadened the scope of their activities, and for some time took charge of sanitary control, education and commerce in the region.

At the end of the 1940's, the Evangelical missionaries began to settle in the area. Initially, the conversion of the Baniwa to the Evangelical faith bore all the signs of a Millenarian movement. With anti-Catholic messages and preaching redemption and the end of suffering, missionary Sophia Müller converted the majority of the Içana Indians. Although they sought to keep away from white people, the Baniwa, after suffering from the system of bosses and tradesmen, accepted the Evangelical faith as a means of resisting white domination. To counter the Evangelical advance, the Assunção Salesian Mission was built in the Lower Içana; this produced a division between Evangelical tribes and Catholic tribes.

This brief description of the process of colonization and land occupation allows us to conclude that the native communities that currently live in the Rio Negro have a culture which results from a blend of ancient Indian rituals and religious beliefs with European and North American origins, besides different aspects of Brazilian culture brought by those who moved to the area for work - due to governmental incentives to populate the Amazon, to the Armed Forces and, more recently, to the actions carried out by Brazilian and international NGOs, among others. Thus, to understand the current culture and lifestyle of the native peoples, it is necessary to look at the socio-historical context and recognize that the different influences create a kaleidoscope of images which transform according to the angle in which they are observed. 


\section{FOIRN's background}

The emergence of FOIRN stems from the effect of the intensified presence of the military, prospectors and mining companies in the Upper Rio Negro region as from the 1970's. During this period, the National Integration Plan (PIN) raised military presence in the area. In 1985, with the intention of implementing a military-political strategy of occupation and border defense, the Brazilian government proposed the Projeto Calha Norte (PCN). Implementation of this project caused several conflicts between the Indians and the military. There were also groups that defended economic interests in exploiting the region's natural resources - mainly mining companies, which sought to gradually gain space. Thus, in the First General Meeting of the Indigenous Peoples of the Rio Negro, carried out in 1986, the main topic was the need to fight for land demarcation and for the guarantee of indigenous land rights.

In the following year, a second assembly was held to discuss the use of indigenous lands in the region. There were over 300 participants, including Indians from Rio Negro and representatives of governmental agencies, such as the National Indian Foundation (Funai), the National Security Council (CSN), the Armed Forces and the Ministry of Agrarian Reform and Development (MIRAD). Also attended the event members of Indian organizations active at the time, such as UNI (Union of Indian Nations), anthropologists and researchers from support entities involved with the Rio Negro issues, as well as local politicians, tradesmen and representatives from mining companies interested in the region, such as Paranapanema and Gold Amazon.

For 16 years the Rio Negro Indian leaders had fought for government recognition of their collective rights to land ownership. At this event, carried out with the financial and logistic support of the federal government, a number of other topics were discussed, such as the relationship of the Indians with the government and the problems and demands of the indigenous communities. All discussions pointed to an evident need of the native peoples to fight for their autonomy over the region and over their communities. On the last day of the Meeting everyone agreed on the importance of having a unified Indian representation for the region and, an organization which would act on behalf of the Rio Negro communities, was created. The federative model was chosen in order to maintain unity and keep the autonomy of the local associations. In this manner, a vote was carried out and the first directors of FOIRN were elected on April 30th,1987.

The first group of leaders to take over the organization had a number of problems, culminating in the president's resignation due to political pressure. In 1990, a new board of directors was elected, taking over in the midst of a financial crisis. There was no money for basic needs, let alone salaries.

The new board of directors made an immediate diagnosis of the Indian movement in the Rio Negro area up to that point, and elaborated a bi-annual plan (1990/1991). They counted on advisory help from the Norte I section of the Conselho Indigenista Missionário (CIMI). This plan, released to a number of support entities, obtained financial assistance from Belgian development agency Broederlijk Delen, at the value of U\$ 30,000.00 (Peres 2003, p. 161, translated by the authors).

From this point on, FOIRN began to elaborate a number of projects and to set up support and advisory agreements with international cooperation agencies and non-governmental organizations, allowing construction of its own premises with space for meetings and assemblies with large groups of people, built according to traditional architecture and materials (Maloca style), a commercial space for sale of 
native art and craft, equipment, boats and motors to improve transport of Indian leaders among the communities, among others. An important point was the implementation of a radio communication network which placed radio sets in over 100 communities, allowing contact with the FOIRN head office in São Gabriel. This system was very important as regional geography places many barriers to integration and communication, and the radio network allows the transmission of information both from the head office and from the tribes.

\section{FOIRN organizational model}

FOIRN is a federation which currently gathers some 60 small formally structured local Indian organizations, which represent the population of the region's indigenous communities, besides professional categories of Indian teachers and health agents. Currently FOIRN represents 750 communities within the Rio Negro basin and the affiliated associations make up the base, which by means of secret votes, elects the representatives which occupy the main decision-making positions within the organization.

The Federation is organized into five sub-regions and has three main decision-making bodies. The five sub-regions - Lower Rio Negro, Tiquié and Lower Uaupés, Upper Rio Negro and Xié, Baniwa and Coripaco and lauaretê District, which includes the Upper and Middle Rio Uaupés region and the Rio Papuri - were defined with basis on the main rivers and tributaries in the region, which generally have different ethnic groups living along their banks.

The main decision-making bodies of FOIRN are the General Assembly, the Council of Directors and the Executive Board. The General Assembly is the highest level of decision-making and meets every two years at the FOIRN's Maloca in São Gabriel da Cachoeira, besides in extraordinary circumstances if necessary. It is made up of representatives from the affiliated organizations with voting rights. The meetings are moments for debate and decisions about themes relevant to FOIRN and the Indian movement of the Rio Negro region. The Council of Directors meets three times per year and is formed by five councilors from each region, chosen by the base associations. Its role is to supervise project execution and accompany the work of the Directors. The Executive Board has five Directors, elected in each sub-region by means of votes in a local assembly, guaranteeing representation for all the territorially covered base. The president of the organization is elected during the General Meeting, which decides which of the five Directors will take on this role. The Executive Directors have the job of carrying out the Federation's programs and projects.

Besides these three decision-making bodies, the FOIRN structure also counts on Regional Coordination Units, Departments and Sectors. The Regional Coordination Units were implemented in 2008 with the aim of forging a day-to-day link between the affiliated associations and the Executive Directors, working directly with the local associations to plan actions and discuss demands, which are then taken to the Directors in order to unify planning. The Regional Coordination Units obey the geographical division of sub-regions and are formed by a coordinator, a vice-coordinator and a treasurer, chosen by votes among candidates chosen from among the delegates of the affiliated associations during the local assemblies. The Departments work from the FOIRN head office on thematic issues, transversally with the directors. The Departments of Education and Social Control, key issues for the organization, have coordinators and vice-coordinators chosen from among the elected directors with basis on their political knowledge of each 
area. The Departments of Women and Youth have coordinators elected by the respective groups that they represent in the local assemblies. The Federation also has three sectors, which are responsible for the administrative areas of finances, communication and supplies.

FOIRN finances its projects and activities with donations from international development agencies; especially HORIZONT3000, an Austrian non-governmental organization for development with has been supporting the organization since its first years. It also counts on partnerships with Brazilian organizations - mainly the Instituto Socioambiental (ISA). The Federation is currently going through a process of internal debate to define how to raise funds among the affiliated organizations of professional categories, such as those who represent the teachers and health agents, in order to become less dependent on external donations, since the Brazilian economy is in rapid growth and, for this reason, the country is no longer a priority for many international development agencies.

\section{Land rights strategy}

\section{The right to land: summary of institutional context}

Since the colonization of Brazil, indigenous land rights have had different status and recognition by law. With the beginning of colonization in 1500, the whole Brazilian territory was considered an integral part of Portugal's domain and, although the laws of that era often recognized indigenous sovereignty and territorial rights, there was a wide gap between legal instruments and practice.

From the time when the country became independent in 1822 there have been several constitutions. Brazil's first constitutions didn't mention indigenous land rights. It was only in 1934 that indigenous rights to land possession were addressed in a constitution for the first time, as well as the exclusive federal jurisdiction to legislate over indigenous rights, principles that were kept in the following legal texts with minor changes. The 1967 Constitution that followed the military coup in 1964 declared, for the first time, that indigenous lands are patrimony of the Union, keeping the permanent possession provisions and recognizing indigenous rights to exclusive use of its natural resources. Also, a law was enacted during the military regime known as the Indian Statute (Law 6001-1973) which reinforced the integrationist perspective and established in its articles, among others, various provisions about the legal status of Indians in regards to civil and criminal liability, the degrees of acculturation of the Indians and the parameters for their emancipation and incorporation into the national community. It also defines a typology of indigenous lands that, in practice, are no longer respected, although this law is still in place.

In this context, the Brazilian democratic process, crowned by the promulgation of the 1988 Constitution, was a landmark for indigenous land rights. It defined indigenous lands as those "inhabited by them in permanent manner, those used for productive activities, those indispensible for the preservation of those environmental resources necessary for their well-being and for their physical and cultural reproduction, according to their uses, customs and traditions" (Constituição da República Federativa do Brasil, 1988, Article $231, \S 1 .^{\circ}$, translade by the authors). In addition, it stipulates that the lands are federal property, and that indigenous peoples' groups have the right to permanent possession and exclusive use of the soil's wealth and of the rivers and lakes which exist within the area. 
Another important dimension of the current Brazilian Constitution is the recognition of indigenous land rights as original, in other words, as previous to the creation of the State itself (Cunha, 1988) - the Indians' rights to a determined area of land do not depend on formal recognition by the State. However, also according to the Constitution, the State is under obligation to promote recognition of Indian lands, defining the area and marking out the borders. Thus, in order to carry out this obligation, the federal government follows a long administrative demarcation process, currently regulated by Decree 1,775, dating from January 8th 1996. The process begins with the identification stage, when a technical group, led by an anthropologist, elaborates a report containing anthropological, historical, sociological, juridical, environmental and cartographic studies. At this stage, the decree establishes participation by the indigenous group, recognizing its particular forms of political representation. The next step is the analysis, approval and publication of the report by Funai. This is followed by the stage where, during a three-month period, all interested parties - including municipalities and states - can dispute the report and request compensation. Next, Funai will review the motives and proof presented by any party contesting the report, which is evaluated by the Ministry of Justice, which can then declare land demarcation, determine further necessary investigation, or turn down the area identification according to decisions based on the Constitution. If the land has its area declared, the next step is the physical demarcation of the borders and the priority resettlement of any non-Indian inhabitants (who have the right to receive compensation for any improvements introduced in the period previous to the identification process). The final stages of the demarcation procedure are the homologation by decree by the President of the Republic and the registration at the deeds office.

However, even though the legal recognition of indigenous lands have advanced and the acknowledgement of indigenous peoples' rights as never seen before in Brazil's legal framework and practice, in reality, land rights and the delimitation of indigenous lands are still complex issues. The constitution stipulates that all indigenous lands should have been delimited by 1993, but there are still several indigenous lands not recognized by the government. Furthermore, land conflicts, in areas officially recognized or not, are very present in many parts of the country, as a result of economic, political and territorial disputes.

\section{FOIRN and the demarcation of lands in the Upper Rio Negro region}

The mobilization of the Indian peoples in the Upper Rio Negro region for legal recognition of their land began in the early 1970's, when Tukano groups from Pari Cachoeira sent letters with maps and demands to the president of Funai, requesting the demarcation of their lands as a continuous area, according to Buchillet (1991). It was not until 1979 that Funai presented a first delimitation proposal for the creation of an Indian reservation in the area, without, however, contemplating all the areas claimed by the Indians. Throughout the following decade, although Funai presented other proposals, the situation of legal imprecision remained which, along with the discovery of gold in the area, encouraged the invasion of nonIndian prospectors. In 1985, the conflicts grew steadily worse due to occupation of land by two mining companies, Paranapanema and Gold Amazon, which were authorized by the government to carry out research in the region, resulting in the deaths of both miners and Indians.

Due to the serious nature of the conflicts, other demarcation proposals were presented by Funai, but did not advance, due to the military and commercial interests in the region. This took the leaderships from the Association of the Union of the Indian Community of Rio Tiquié (Ucirt) to the county's capital in 1986 to 
present their demand for non-fragmentation of their traditional lands to high employees of the Brazilian Federal Government during the military regime, such as the general secretary of the National Security Council (CSN). The meeting's result was not positive for the Indians: the military not only rejected the proposal but presented an alternative highly unfavorable to Indian interests: the creation of Indian Agricultural Colonies, with the land divided into lots which could be acquired by the families. After returning to Rio Negro, the leaderships gathered in assembly and decided to continue positioning themselves in favor of collective land, in other words, the demarcation of Indian land in a continuous area. Eventually, after much negotiation, some leaders made deals with the government and the model of demarcation in Indian colonies was accepted as a solution to guarantee land ownership and bring development to the region. As a result, in 1988 three Indian Colonies and two National Forests were marked out.

Thus, in the period between 1987 and 1992, twelve new associations emerged which focused on the debate surrounding the proposals for demarcation of the Rio Negro land. These organizations were basically divided between those who supported the proposal for demarcation of continuous land and those who defended the demarcation of Indian colonies, along with the promise that the government would invest in social assistance and community development projects. The associations were formed based on geographical proximity and composed by groups of villages located along a branch of a river, along one or more rivers, or in a district and they gathered a variety of ethnic groups.

The Indians associated to FOIRN and contrary to this form of demarcation used several resistance strategies; from removing the markers which set out the colony limits to formalizing appeals to the Attorney-General's Office, making the claim for demarcation of Indian lands in the Upper Rio Negro as continuous territory. Thus, from 1990 on, FOIRN has been involved in a fight for demarcation which involved several legal proceedings. We can say that FOIRN was victorious, as in 1998 the President of the Republic homologated an extension of 10.6 million hectares of continuous land. However, there is still land that needs to be homologated, especially along the lower and mid Rio Negro.

It is worth pointing out that, besides its work in the political sphere and in setting out claims, FOIRN had an important role in the demarcation process itself, as the adopted model established two work groups: one made up of an engineering company responsible for establishing the geodesic points, and another made up of the directors of FOIRN with advisors from the Instituto Socioambiental, responsible for formulating the plan and marking out the territory. The process was highly participatory, with demarcation teams travelling to the different regions and explaining to the local Indians what demarcation meant. In each region, besides the official plaque which recognized the Indian lands, the local leaderships received official documents and demarcation maps.

After the homologation of the Indian lands, FOIRN, in partnership with non-governmental organizations, sought to propose to the government public policies which would allow the sustainable development of the region and which were in accordance with the wishes of the region's indigenous population.

\section{Final considerations}

In the different regions of Brazil, recognition of indigenous rights has been the center of many controversies, prejudice and political and economic dispute. In the Rio Negro region, the process has been no different and all achievements are the product of the Indians' work and the strategies developed 
in order to pressure the government to recognize the Indians as true citizens. In this sense, the creation of the Federation of Indian Organizations of the Negro River in 1987 allowed the gathering of different Indian ethnicities within a common project. This organization began to organize the 23 ethnicities that live in the region and to defend the collective interests.

Despite the Original People's movement having advanced a great deal since the 1970's in terms of organization, FOIRN's experience is innovative in a number of ways. In the first place it is important to point out that the state of Amazonas is home to $15 \%$ of the country's self-declared Indian population, and that in São Gabriel da Cachoeira the Indians are the absolute majority, a very different reality from other locations in Brazil, where the Indian populations are disperse minorities. Besides, the region, due to its difficult access, has been less exposed to exploration and occupation motivated by economic interests. Another reason may be the regional presence, for several decades, of non-governmental organizations such as the Centro Ecumênico de Documentação e Informação (CEDI), which later originated the Instituto Socioambiental (ISA), an important ally of FOIRN since its foundation. And lastly, it is worth pointing out that in the Rio Negro the different ethnicities have been able to forge an alliance and create an institutional machine within which even groups who are historic rivals can now work together towards goals which are important to all. However, there are still non-resolved issues within the organization, such as the representation of the Hup'däh minority and of the women who, despite running a department, are still under-represented at the higher decision-making levels within the organizational structure.

This organizational strategy has allowed the Indian population of the Upper Rio Negro active participation in the land demarcation process, with their opinions heard and respected. There are, however, still indigenous lands in the region which have not even been identified yet, especially in the lower and mid Rio Negro, in the Santa Isabel and Barcelos' towns, keeping the issue of land rights on the agenda for FOIRN and its affiliated associations.

Indian mobilization in a representative organization has also allowed the acquirement of resources by means of partnerships with developmental organizations and non-governmental organizations, both national and international, in order to carry out projects which strengthen the ethnic identity of the several communities and promote their self-government.

One of the biggest challenges to face the indigenous moment in the Rio Negro region, and especially FOIRN, is how to take part in the game of representative democracy and political parties. In 2008, for the first time in Brazil and in São Gabriel da Cachoeira, an Indian mayor and vice-mayor were elected. As these were people who had participated intensely in the indigenous movement and had occupied positions within FOIRN, their election may be seen as an indicator that the local population, formed by an Indian majority, recognizes the importance of having Indians within the municipal administration and that the lessons learnt by these leaderships within FOIRN have given them the ability to take on governmental roles. However, contrary to the expectations of the FOIRN leaderships and the vice-mayor, the mayor has formed an administration which does not include the local leaderships, and has not carried out the expected dialogue with FOIRN or put into practice the expected public policies, such as the full implementation of the Municipal Plan, elaborated at the end of the previous administration.

FOIRN is a unique case of organization within the Brazilian indigenous movement and its trajectory is a privileged source for other organizations in the country and in the world to seek inspiration and learn from its successful strategies. Its work in the last few years has set it apart as a political actor of local, regional 
and national relevance. It is an organization which has been active in the fight for constitutional rights and in managing and disseminating innovative projects within its sphere of action, as described in this text. Besides, it is an organization which has proved efficient in carrying out a democratic dialogue with the government, by means of advocacy, and by the social control over public policies in a number of thematic areas, putting forward the interests of the communities it represents with different government bodies. Lastly, it is an organization which has known how to remain united and strong when faced by the dividing effect of the political party game.

\title{
References
}

Buchillet, Dominique (1991). Pari Cachoeira: o laboratório Tukano do projeto Calha Norte. In Povos Indígenas no Brasil 1987/88/89/90. Aconteceu especial (pp. 107-115). São Paulo: CEDI.

Constituição da República Federativa do Brasil. Law of October 5th, Chapter VIII, Articles 231 and 232, 1988.

Constituição da República Federativa do Brasil. Law of January 24th, Title V Article 186, 1967.

Cunha, Manuela Carneiro da (1988). Os índios na nova Constituição brasileira. São Paulo: s.ed.

Decree 1775, January 8th, 1996.

Instituto Brasileiro de Geografia e Estatística, IBGE (2007). IBGE cidades@. Retrieved on March 14th, 2011, from: http://www.ibge.gov.br/cidadesat/painel/painel.php?codmun=130380

Instituto Socioambiental, ISA (2010). Site Povos Indígenas do Brasil. Retrieved on March 14th, 2011, from www.isa.org.br

Oliveira, Fernanda Martinez de (2006). Dilemas de inclusão das diversidades étnicas no federalismo brasileiro: as perspectivas dos povos indígenas. Unpublished Master's Thesis, Escola de Administração de Empresas de São Paulo, Fundação Getulio Vargas (EAESP-FGV).

Peres, Sidnei Clemente (2003). Cultura, política e identidade na Amazônia: o associativismo indígena no Baixo Rio Negro. Unpublished Ph.D. Dissertation, Universidade Estadual de Campinas, Brasil.

\section{Historia editorial}

\author{
Recibido: 15/03/2011
}

Aceptado: 17/06/2011

\section{Formato de citación}

Oliveira, Fernanda Martinez de; Brigagão, Jacqueline y Spink, Peter (2011). The Federation of Indian Organizations of the Negro River's journey for traditional land demarcation in Brazil. Athenea Digital, 11(2), 73-83. Disponible en http://psicologiasocial.uab.es/athenea/index.php/atheneaDigital/article/view/860 


\section{SORIERIGHIS RESERVED}

Este texto está protegido por una licencia Creative Commons.

Usted es libre de copiar, distribuir y comunicar públicamente la obra bajo las siguientes condiciones:

Reconocimiento: Debe reconocer y citar al autor original.

No comercial. No puede utilizar esta obra para fines comerciales.

Sin obras derivadas. No se puede alterar, transformar, o generar una obra derivada a partir de esta obra.

$\underline{\text { Resumen de licencia - Texto completo de la licencia }}$ 
